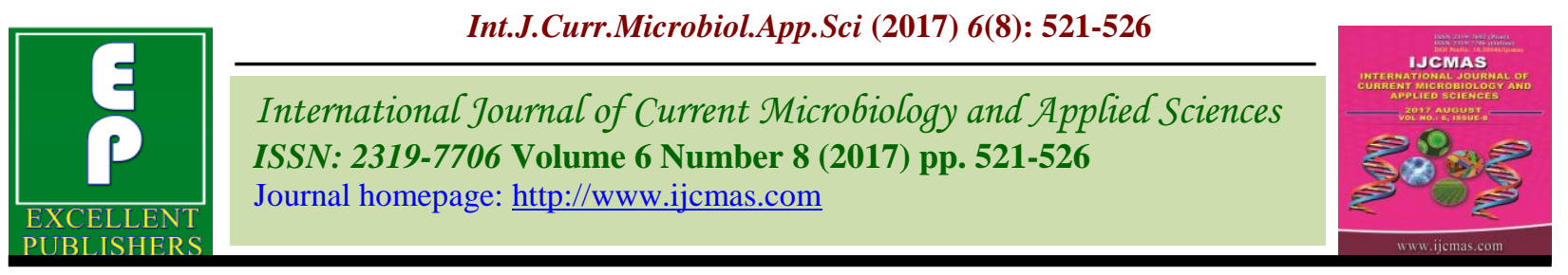

Original Research Article

https://doi.org/10.20546/ijcmas.2017.608.067

\title{
Probiotics as Biocontrol Agent in Post Harvest Disease Management
}

\author{
Polepongu Srilatha ${ }^{1}$ and S.G. Borkar ${ }^{2 *}$ \\ Department of Plant Pathology and Agriculture microbiology, Mahatma Phule Krishi \\ Vidyapeeth, Rahuri, Maharashtra, India \\ *Corresponding author
}

\section{A B S T R A C T}

Use of probiotics for the control of post-harvest diseases has opened new avenue in the management of post-harvest plant pathogens and organic farming. Such probiotics has

\begin{tabular}{|c|c|}
\hline Keywords & $\begin{array}{l}\text { never been used in the crop production or crop protection programme in Agriculture. The } \\
\text { post-harvest pathogens particularly Rhizopus, Aspergillus, Penicillium and Alternaria can }\end{array}$ \\
\hline $\begin{array}{l}\text { Probiotics, } \\
\text { Post harvest } \\
\text { Pathogens, } \\
\text { Disease } \\
\text { management. }\end{array}$ & $\begin{array}{l}\text { be checked as a post-harvest pathogen by sprays of probiotics under natural field } \\
\text { conditions when the load of inoculums of these post-harvest pathogens is less in fruits. } \\
\text { Application of probiotic as pre-harvest field spray helps to manage the post-harvest } \\
\text { disease. The pre-harvest field application of commercial probiotics Sporocheck and } \\
\text { MPKV probiotics has beneficial effect for management of post-harvest pathogens }\end{array}$ \\
\hline Article Info & Aspergillus infection. For the control of Rhizopus pathogen MPKV probiotics was \\
\hline $\begin{array}{l}\text { Accepted: } \\
\text { 04 June } 2017 \\
\text { Available Online: } \\
\text { 10 August } 2017\end{array}$ & $\begin{array}{l}\text { effective as compared to commercial probiotics. similarly commercial probiotics Darolac, } \\
\text { Sporocheck and MPKV probiotics was effective to inhibit/control the growth of post- } \\
\text { harvest pathogens Penicillium and Alternaria on the harvested fruits (having natural load } \\
\text { of pathogen inoculum) the efficacy of probiotics against post-harvest pathogens, indicated }\end{array}$ \\
\hline & $\begin{array}{l}\text { that probiotics can be used in the management of post harvest disease and there can form } \\
\text { an integral part of organic farming system. }\end{array}$ \\
\hline
\end{tabular}

\section{Introduction}

During storage, a number of fungi are known to cause spoilage of fruits. Under tropical conditions considerable losses are occurred due to rots caused by Rhizopus spp., Penicillium spp., Aspergillus spp., Botrytis cinerea, Botryodiplodia spp., Bipolaris spp., Curvularia spp., Fusarium spp., and are becoming limiting factor for successful fruit harvest management (Thomas, 1986). The total estimated losses of fruits and vegetables in India due to inadequate post-harvest handling, transportation and storage are reported to the extent of 20-25 per cent (Singh, 1981). These losses in terms of monetary value are more than 1.5 billion dollars annually. Post-harvest losses caused by microorganism accounts for millions of dollars in perishable produce every year (Narayana Swamy, 2005). To minimize these losses and the produce, it is very necessary to control the post-harvest diseases. Post-harvest diseases can be controlled by biological, chemical and physical treatments (Mehrotra et al., 1998). These includes the use of bioagents and botanicals as biological treatments while chemical treatments includes use of antibiotics, fungicides, oils and as physical treatments vapor emitting compounds. The 
post-harvest diseases minimized by application of therapeutical fungicides as preharvest treatment under field conditions, possess a serious threat of residues of these fungicidal chemicals on consumable product and therefore their use is being restricted worldwide. Therefore a novel method of biocontrol of these post-harvest diseases is a need of the day to save our produce. These biocontrol agents should be safe for human, as in case of probiotics.

Probiotics are defined as the micro organisms which are beneficial in the human health (Nichols, 2007). These are orally administered or given in food supplements and are present in the gastrointestinal tract of human beings. These are also used for the health benefits of animals, birds and fishes (Sharma, 2007 and Gatesoupe, 2008). Probiotics occur naturally in the fermented food product such as yoghurt, kefir, sauerkraut, cabbage kimchee and soybeanbased miso and natto. Numerous health benefits have been attributed to probiotics including effects on gastrointestinal tract functions and diseases, immune functions, hyperlipidemia, hypertension and allergic conditions. These also enhance the recovery from fatigue and improved the immune function (Nichols, 2007). The probiotic supplements includes bacteria like Lactobacillus rhamnosus, Bifidobacterium longum, L. salivarius, $L$. plantarum, $L$. paracasei, B. lactis type and Streptococcus facealis, Clostridium butyricum and Bacillus masentericus and some edible yeast species. As the probiotics are consumed orally and beneficial to the human health their presence on the consumable fruits will not have any harmful affect on the human. As the probiotics are known to control pathogenic infections in human and are safe microbial formulations, there use to control post harvest fruit pathogen was studied.

\section{Materials and Methods}

\section{Isolation of causal organism}

The collected disease specimens from grape and strawberries were surface sterilized with $1 \%$ sodium hypochloride solution for 2-3 minutes and partly diseased portion with some partly healthy portion was cut with the help of sterilized scissors under aseptic conditions in laminar air flow and kept on potato dextrose media plates. The inoculated Petri plates were then incubated at $25 \pm 2^{\circ} \mathrm{C}$ for 3 days. The fungal growth obtained was purified by mycelial tip isolation method and further identified upto genus level based on their characteristics.

\section{Commercial probiotics}

Sacro (contains Lyophilized saccharomyces boulardi), Darolac (contains L. acidophilus, L. rhamnosus, B. longum and S. boulardi) and Sporocheck (contains Streptomyces faecalis, Clostridium butyricum, Bacillus mesentaricus and Lactic acid bacillus (Lactobacillus sporogenes) are available in the market.

\section{MPKV probiotics}

Probiotics were isolated from respective probiotic sample (Probiotic I, a edile yeast culture isolated from dhokla material; probiotic II, a edible yeast culture isolated from dosa material; probiotic III, a edible yeast culture isolated from bajra flour; probiotic IV, a edible yeast culture isolated from jowar flour and probiotic lactobacillus culture isolated from curd.

\section{In vitro effect of probiotics on post harvest pathogens}

In one litre distilled water 20 gm sugar was added. In it one probiotic sachet of respective probiotic containing one gm of probiotic 
powder was added. This solution was incubated at $28 \pm 2^{\circ} \mathrm{C}$ in $\mathrm{BOD}$ for the growth of probiotic organisms for 3 days. The suspension thus obtained was used for field application. In case of MPKV probiotics one litre distilled water having 2 per cent sugar was taken. A growth of individual MPKV probiotic I, II, III, IV and V from a single tube was added to this solution and incubated at 28 $\pm 2^{\circ} \mathrm{C}$ in $\mathrm{BOD}$ for the growth of probiotic organisms for 3 days. Two months old grape bunches (of 12.8 sugar brix) was harvested and brought to laboratory. There grape bunches were sprayed with probiotic solutions prepared as above and air dried. Such bunches were packed in package contains and kept at ambient temperatures for 8 days. Sugar brix in there probiotic sprayed bunches were measured using refractometer and readings are expressed in sugar brix.

Field evaluation of probiotics for biocontrol efficacy against post harvest pathogens

Two probiotics viz., Sacro and Darolac which were effective under in vivo tent to simulate sugar brix in harvested grape berries were tested under field conditions for their efficacy. In one litre distilled water 20 gm sugar was added. In it one probiotic sachet of respective probiotic containing one $\mathrm{gm}$ of probiotic powder was added. This solution was incubated at $28 \pm 2^{\circ} \mathrm{C}$ in BOD for the growth of probiotic organisms for 3 days. Under field conditions the probiotic sprayed bunches were harvested after 1 day, 8 days and 15 days of probiotic sprays. These grape bunches were packed in cardboard boxes along with control grape bunches (without probitotic spray). The TSS in the grape was taken after 15 days of packing.

\section{Preparation of probiotic solutions}

Commercial probiotic suspension for field application was prepared as fallows. In one litre distilled water 20 gm sugar was added. In it one probiotic sachet containing one gm of probiotic powder was added. This solution was incubated at $28 \pm 2^{\circ} \mathrm{C}$ in BOD for the growth of probiotic organisms for 3 days. The suspension thus obtained was used for field application. In case of MPKV probiotics one litre distilled water having 2 per cent sugar was taken. A growth of individual MPKV probiotic I, II, III, IV and V from a single tube was added to this solution and incubated at 28 $\pm 2^{\circ} \mathrm{C}$ in $\mathrm{BOD}$ for the growth of probiotic organisms for 3 days. The suspension thus obtained was used for field application.

To study the antagonistic effect of probiotics on post-harvested fruits having natural postharvest pathogens (Rhizopus, Aspergillus, Alternaria and Penicillium), the experiments were laid out in vitro conditions. The postharvested fruits were brought to laboratory and sprayed with respective probiotics solutions. There were packed in their respective packing boxes and kept at room temperature for observation on development of post-harvest pathogens. In second experiment, the harvested fruits were brought to laboratory. These were washed with distilled water and dried with air by using air drier. These fruits were then spray inoculated with suspension of respective post-harvest pathogen and again air dried. The respective probiotic suspension was sprayed on these fruits and again air dried. The probiotic treated fruits were packed in their respective packing material as mentioned above and kept at room temperature. The fruits sprayed with pathogen but no probiotic served as control. The observation was taken up to one month for appearance of post-harvest pathogen. Yet in another experiments the fruits (grape berry bunches) under field conditions were sprayed with probiotics. There were then harvested after 8 days and 15 days of probiotic spray and were packed in cardboard grape packing boxes and kept at room temperature. Observations were recorded after 15 days for 
infection of post-harvest pathogens if any. The unsprayed fruits served as control.

\section{Results and Discussion}

Field performance of probiotics in management of natural post harvest fungi in grapes

The results (Table 1a) indicated that the commercial probiotic Darolac, Sporocheck and MPKV probiotic was effective to inhibit/control the growth of post-harvest pathogen Penicillium and Alternaria only but not against the pathogen Aspergillus and
Rhizopus under dual inoculam application. Commercial probiotic Sacro was not at all effective against any test pathogen.

The efficacy of their probiotics was also studied on naturally occurring post harvest pathogens on grape bunches under field conditions. The result (Table $1 \mathrm{~b}$ ) indicated that the commercial probiotics Darolac and MPKV probiotics was effective against four post harvest pathogens i.e., Aspergillus, Rhizopus and Alternaria while Sporocheck was effective against Penicillium, Rhizopus and Alternaria.

Table.1 In vitro performance of probiotics in the management of post-harvest pathogens of grape

a. Efficacy of probiotics in dual inoculation (pre spray of post-harvest pathogen followed by post spray of probiotics)

\begin{tabular}{|l|c|c|c|c|c|}
\hline Post harvest & \multirow{2}{*}{$\begin{array}{l}\text { Pathogen } \\
\text { pathogens } \\
\text { probithout } \\
\end{array}$} & \multirow{2}{*}{$\begin{array}{l}\text { probiotics) } \\
\end{array}$} & \multicolumn{4}{|c|}{$\begin{array}{l}\text { Growth of post harvest pathogen in grape fruit } \\
\text { bunches sprayed with probiotic }\end{array}$} \\
\cline { 2 - 6 } & Sacro & Sporochek & Darolac & $\begin{array}{c}\text { MPKV } \\
\text { probiotics }\end{array}$ \\
\hline Aspergillus & + & \pm & \pm & \pm & \pm \\
\hline Penicillium & + & + & - & - & - \\
\hline Rhizopus & + & + & \pm & \pm & \pm \\
\hline Alternaria & + & \pm & - & - & - \\
\hline
\end{tabular}

$+=$ Fungal growth present. $\pm=$ Traces of fungal growth. $-=$ No fungal growth

b. Efficacy of probiotics on naturally occurring post harvest pathogen in grape bunches (grape bunches sprayed with probiotics)

\begin{tabular}{|l|c|c|c|c|c|}
\hline \multirow{3}{*}{ Pathogens } & \multicolumn{3}{|c|}{$\begin{array}{c}\text { Growth of Naturally occurring post harvest } \\
\text { pathogen in grape bunches sprayed with } \\
\text { probiotics }\end{array}$} & $\begin{array}{c}\text { Growth of post } \\
\text { harvest pathogens } \\
\text { in non probiotic } \\
\text { sprayed grape } \\
\text { bunches }\end{array}$ \\
\cline { 2 - 5 } & Darolac & Sacro & Sporocheck & $\begin{array}{c}\text { MPKV } \\
\text { Probiotics }\end{array}$ & + \\
\hline Aspergillus & - & \pm & \pm & - & + \\
\hline Penicillium & - & \pm & - & - & + \\
\hline Rhizopus & - & \pm & - & - & + \\
\hline Alternaria & - & \pm & - & - & + \\
\hline
\end{tabular}

$\pm=$ Traces of fungal growth.

- = No fungal growth 
Table.2 Field performance of probiotics in the management of post-harvest pathogen of grape

a. On Aspergillus pathogen

\begin{tabular}{|c|c|c|c|c|c|}
\hline $\begin{array}{c}\text { Harvesting } \\
\text { period after } \\
\text { probiotic } \\
\text { Spray }\end{array}$ & \multicolumn{5}{|c|}{ Presence of Aspergillus in grape bunches sprayed with probiotic } \\
\cline { 2 - 6 } & Darolac & Sacro & Sporocheck & $\begin{array}{c}\text { MPKV } \\
\text { probiotics }\end{array}$ & $\begin{array}{c}\text { Control } \\
\text { (unsprayed) }\end{array}$ \\
\hline 8 Days & + & ++ & - & - & + \\
\hline 15 Days & + & + & - & - & + \\
\hline
\end{tabular}

b. On Rhizopus pathogen

\begin{tabular}{|c|c|c|c|c|c|}
\hline \multirow{2}{*}{$\begin{array}{c}\text { Harvesting } \\
\text { period after } \\
\text { probiotic } \\
\text { Spray }\end{array}$} & \multicolumn{3}{|c|}{ Presence of Rhizopus in grape bunches sprayed with probiotic } \\
\cline { 2 - 6 } & Darolac & Sacro & Sporocheck & $\begin{array}{c}\text { MPKV } \\
\text { probiotics }\end{array}$ & $\begin{array}{c}\text { Control } \\
\text { (unsprayed) }\end{array}$ \\
\hline 8 Days & - & ++ & ++ & - & ++ \\
\hline 15 Days & ++ & ++ & + & - & ++ \\
\hline
\end{tabular}

The much efficacy of probiotics to control natural post harvest infection may be due to fact that the natural inoculum load of post harvest pathogen may be less to obtain cent percent control. The results (Table 2a) indicated that commercial probiotic Sporocheck and MPKV probiotic were able to check the infection of Aspergillus fungus as there was no growth of Aspergillus in the probiotic sprayed bunches while it was present in the unsprayed fruit bunches. The probiotics Darolac and Sacro was not effective in the control of Aspergillus infection. For the control of Rhizopus pathogen MPKV probiotic was effective as compared to commercial probiotic (Table 2b).

Kailasapathy and Chin (1999) reported the use of probiotic organisms as live supplements, with particular emphasis on Lactobacillus acidophilus and Bifidobacterium spp. Probiotic bacteria are increasingly used in food and pharmaceutical applications to balance disturbed intestinal microflora and related dysfunction of the human gastrointestinal tract. The pharmaceutical applications of probiotics has been reported by several other workers also (Molin, 2001; Isolauri et al., 2001; Shima et al., 2007; Hussein and Aumara, 2006 and Oliveria et al., 2002). However there is no report of probiotic use on plant disease management. Then this is the first report on use of probiotics in plant disease management.

\section{References}

Gatesoupe, F.J. 2008. Different methods to reduce antibiotic use in farmed fish. Improving farmed fish quality and safety. pp. 199-237.

Hongyin Zhang, Renping Li and Weimin Liu. 2011. Effects of Chitin and Its Derivative Chitosan on Post-harvest Decay of Fruits: A Review. Int. J. Mol. Sci., 12: 917-934.

Hussein, G.A.M. and Aumara, I.E. 2006. 
Preparation and properties of probiotic frozen yoghurt made with sweet potato and pumpkin. Arab Universities $J$ Agri. Sci., 14(2): 679-695.

Isolauri Erika, Yelda Sutas, Pasi Kankaanpaa, Heikki Arvilommi and Seppo Salminen. 2001. Probiotics: effects on immunity. American Soc. Clin. Nutri., 73(2): 444-450.

Kailasapathy Kaila and James Chin. 1999. Survival and therapeutic potential of probiotic organisms with reference to Lactobacillus acidophilus and Bifidobacterium spp. Immunol. Cell Biol., 78: 80-88.

Mehrotra, L.A., Mahamoud, S.E.M. and Kottob, M.A. 1998. Fungus diseases of fruits and grapes in storage. IZV. AN Mola SSR. Biol. Ikhion, N. No.1: 49-53 From Review Plant Path., 55(12): 1095.

Molin Goran. 2001. Probiotics in foods not containing milk or milk constituents, with special reference to Lactobacillus plantarum. Am. J. Clin. Nutr., 73(2): 380-385.

Narayana Swamy, P. 2005. Post-harvest Pathogen and Disease Management. Wiley Publication, p. 578.

Nichols, A.W. 2007. Probiotics and athletic performance: a systematic review. Curr.
Sports Med. Reports, 6(4): 269-273.

Oliveria, M.N., Sodini, I., Remeuf, F., Tissier, JP. and Corrie, G. 2002. Manufacture of fermented lactic beverages containing probiotic cultures. J. Food Sci., 67: 2336-2341.

Shima Tatsuichiro, Kouhei Fukushima, Hiromi Setoyama, Akemi Imaoka, Satoshi Matsumoto, Taeko Hara, Kazunori Suda and Yoshinori Umesaki. 2007. Differential effects of two probiotic strains with different bacteriological properties on intestinal gene expression, with special reference to indigenous bacteria. FEMS Immunol. Med. Microbiol., 51(1): 69-77.

Singh, K.K. 1981. Need for the development of efficient marketing system for efficient distributions of Horticultural produce. Paper delivered at the $2^{\text {nd }}$ workshop of All India Coordinated Research Project on Post-harvest Technology of Horticultural Crops held at I.A.R.I New Delhi, Dec. 3 to 4.

Thomas, P. 1986. Radiation preservation of foods of plant origin. Part V. Temperature fruits: Pome fruits, stone fruits and berries. CRC Crit. Rev. Food Sci. Nutr., 24: 357-400.

\section{How to cite this article:}

Polepongu Srilatha and Borkar, S.G. 2017. Probiotics as Biocontrol Agent in Post Harvest Disease Management. Int.J.Curr.Microbiol.App.Sci. 6(8): 521-526.

doi: https://doi.org/10.20546/ijcmas.2017.608.067 